\title{
Diagnostyka i leczenie kiły w Europie - stanowisko Grupy Ekspertów Polskiego Towarzystwa Dermatologicznego
}

\author{
Agnieszka B. Serwin', Sławomir Majewski², Ryszard Żaba ${ }^{3}$, Anna Wojas-Pelc ${ }^{4}$, Joanna Maj', Jacek Szepietowski ${ }^{5}$ \\ 'Klinika Dermatologii i Wenerologii Uniwersytetu Medycznego w Białymstoku \\ ${ }^{2}$ Katedra Dermatologii i Wenerologii Warszawskiego Uniwersytetu Medycznego \\ 3Zakład Dermatologii i Wenerologii Wydziału Nauk o Zdrowiu Uniwersytetu Medycznego im. Karola Marcinkowskiego w Poznaniu \\ ${ }^{4}$ Katedra i Klinika Dermatologii Uniwersytetu Jagiellońskiego Collegium Medicum w Krakowie \\ ${ }^{5}$ Katedra i Klinika Dermatologii, Wenerologii i Alergologii Uniwersytetu Medycznego we Wrockawiu
}

Przegl Dermatol 2015, 102, 476-478

Po przetłumaczeniu i skomentowaniu europejskich zaleceń dotyczących diagnostyki i leczenia rzeżączki Zarząd Polskiego Towarzystwa Dermatologicznego (PTD) przedstawia polskie tłumaczenie Europejskich zaleceń diagnostycznych i leczniczych dotyczących kiły, opublikowanych w Journal of European Academy of Dermatology and Venereology w grudniu 2014 r. (wersja online była dostępna w październiku 2014 r.) [1]. Powyższe zalecenia, będące trzecią (po zaleceniach z 2001 i 2008 r.), uaktualnioną ich wersją, są jednymi z najnowszych rekomendacji terapeutycznych dotyczących zakażeń przenoszonych drogą płciową. Zostały opracowane przez ekspertów europejskich na podstawie dostępnych dowodów medycznych i zaaprobowane przez najważniejsze europejskie organizacje i towarzystwa naukowe reprezentujące nie tylko dermatologów i wenerologów. Szczególne uznanie budzi najwyższy standard poszukiwania dowodów medycznych, na podstawie których zostały przygotowane.

W Polsce zalecenia dotyczące leczenia kiły i kontroli po jej leczeniu, na których opierali się w swojej pracy dermatolodzy-wenerolodzy, zostały opracowane w 1974 r. i od tego czasu nie były zmieniane pomimo postępu nauk medycznych i istnienia nowych dowodów [2].

Oficjalne dane na temat zapadalności na kiłę nabytą w Polsce wydają się optymistyczne: w XXI w. (lata 2001-2014) średni współczynnik zapadalności wynosił 2,0 na 100000 mieszkańców, jego wartość wahała się od 1,6 (2005 r.) do 2,6 (2009 i 2013 r.) i była niższa niż w krajach sąsiadujących z Polską. Niepokój natomiast może budzić występowanie kiły u kobiet ciężarnych (ponad 650 przypadków w wymienionych latach), a przede wszystkim - kiły wrodzonej (192 przypadki, najwięcej - 32 w 2012 r.).

Przedstawiając najnowsze zalecenia europejskie dotyczące diagnostyki i leczenia kiły, Grupa Eksper- tów PTD i Sekcja Wenerologiczna PTD pragną zwrócić szczególną uwagę na następujące zagadnienia:

1. Diagnostyka kiły:

- badanie w ciemnym polu widzenia mikroskopu świetlnego, mimo ograniczeń dotyczących swoistości i czułości, jest jedną z zalecanych metod diagnostyki bezpośredniej, umożliwiającą pewne rozpoznanie kiły I i II okresu,

- wprowadzenie metod diagnostyki molekularnej, opartych na amplifikacji kwasów nukleinowych Treponema pallidum, do diagnostyki zmian w okolicach, gdzie mogą bytować krętki saprofityczne, powinno być poprzedzone zagwarantowaniem wysokiej kontroli jakości w laboratorium oraz walidacją danej metody,

- odczyny niekrętkowe powinny być wykonywane tylko w modyfikacji ilościowej, a krętkowe - w modyfikacji jakościowej,

- komercyjnie dostępne tzw. szybkie testy przyłóżkowe (ang. point-of-care tests) nie powinny być stosowane w krajach o niskiej zapadalności, zatem także w Polsce,

- zalecane algorytmy diagnostyki serologicznej kiły uwzględniają także badanie przesiewowe za pomocą odczynu klasycznego (niekrętkowego), a następnie potwierdzenie dodatniego wyniku odczynem krętkowym w tej samej porcji surowicy - ten algorytm jest stosowany w Polsce; w przypadku badania dużej grupy osób, np. w stacjach krwiodawstwa, uzasadnione jest badanie przesiewowe za pomocą zautomatyzowanych odczynów krętkowych (EIA, CIA),

- odczyny FTA i Nelsona-Mayera nie są wymieniane w zaleceniach i należy rozważyć zaprzestanie ich wykonywania w diagnostyce kiły w Polsce,

- szczególnie istotna jest poprawna kwalifikacja pacjentów z kiłą do wykonania punkcji lędźwiowej: badanie takie nie jest zalecane u pacjentów z kiłą 
wczesną (HIV-dodatnich i HIV-ujemnych), gdy nie stwierdza się odchyleń w badaniu neurologicznym (także psychiatrycznym), okulistycznym i laryngologicznym,

- wskazaniami do zbadania płynu mózgowo-rdzeniowego (PMR) u pacjenta z kiłą są: odchylenia $\mathrm{w}$ badaniu neurologicznym (także psychiatrycznym), okulistycznym lub laryngologicznym bez względu na okres kiły oraz kiła trzeciego okresu,

- badanie takie należy rozważyć u pacjentów bez objawów klinicznych: a) HIV-dodatnich z kiłą późną, jeśli liczba komórek CD4+ wynosi $\leq 350 / \mathrm{mm}^{3}$ $\mathrm{i} /$ lub miano odczynu niekrętkowego w surowicy wynosi $>1: 32$; b) jeżeli nie obserwuje się właściwej odpowiedzi serologicznej po leczeniu; c) z kiłą późną leczonych doksycykliną,

- zalecenia nie przedstawiają jednoznacznych laboratoryjnych kryteriów diagnostycznych dotyczących kiły ośrodkowego układu nerwowego (OUN), co w praktyce klinicznej może sprawiać trudności. Grupa Ekspertów PTD rekomenduje kryteria przedstawione $\mathrm{w}$ poprzedniej wersji zaleceń z 2008 r. (dodatni odczyn krętkowy w PMR z liczbą komórek jednojądrowych $>5 \mathrm{w} \mathrm{mm} \mathrm{mm}^{3}$ lub dodatni odczyn VDRL w PMR) [3, 4]. Również miano odczynu TPHA w PMR $>1: 320$ powinno sugerować kiłę OUN.

2. Leczenie kiły nabytej:

- leczeniem I rzutu w kile nabytej wczesnej i późnej, także u kobiet ciężarnych, powinna być długo działająca penicylina benzatynowa (jedna iniekcja 2,4 mln j. w kile wczesnej i trzy - w kile późnej). Ze względu na brak stałej dostępności długo działającej penicyliny w Polsce (podobnie jak w kilku innych krajach europejskich) należy rekomendować także postępowanie określanew zaleceniachjakoleczenie II rzutu - penicyliną prokainową (dawka $600000 \mathrm{j} . /$ dobę przez 14 dni w kile wczesnej i 21 dni w kile późnej). W przypadku uczulenia na penicylinę można zastosować doksycyklinę w dawce $200 \mathrm{mg}$ / dobę przez 14 dni w kile wczesnej i 28 dni w kile późnej. W kile wczesnej można w tej sytuacji podać pojedynczą dawkę azytromycyny (2 g), ale należy pamiętać o coraz częstszych przypadkach oporności krętka bladego na ten lek. Dotychczas nie ma dowodów na oporność krętka bladego na penicylinę i doksycyklinę. Erytromycyna nie jest obecnie zalecana do leczenia kiły;

- zalecenia nie wspominają o "próbie na penicylinę" przed iniekcją, natomiast po iniekcji pacjent powinien być pod obserwacją przez 30 minut;

- nie ma alternatywy dla penicyliny w leczeniu kiły u kobiet w ciąży;

- doksycyklina nie powinna być stosowana w leczeniu kiły OUN; gdy podanie penicyliny krystalicznej (w warunkach szpitalnych) nie jest możliwe, opcją terapeutyczną może być ceftriakson (1-2 g/ dobę i.v. przez 10-14 dni).

3. Przy podejrzeniu kiły wrodzonej u noworodka należy wykonać badania serologiczne (odczyny niekrętkowe i krętkowe - ilościowe, oznaczenie przeciwciał przeciwkrętkowych w klasie IgM), oznaczyć morfologię krwi, parametry funkcji wątroby, stężenie elektrolitów; kontrowersje może budzić zalecane $\mathrm{w}$ tych przypadkach badanie PMR, także u dzieci bez odchyleń neurologicznych. Badanie PMR powinno być wykonane $\mathrm{u}$ dzieci z odchyleniami $\mathrm{w}$ badaniu neurologicznym, tym bardziej że w leczeniu kiły wrodzonej należy zastosować penicylinę krystaliczną (która penetruje do PMR) w dawce 150000 j./kg m.c./ dobę $\mathrm{w} 6$ dawkach podzielonych przez 2 tygodnie.

4. U pacjentów ze współistniejącym zakażeniem HIV postępowanie diagnostyczne i terapeutyczne nie powinno się różnić od stosowanego u osób HIV-ujemnych, zalecana jest natomiast dokładniejsza kontrola po leczeniu. Należy rozważyć badanie PMR u pacjentów HIV-dodatnich z kiłą późną lub o nieznanym czasie trwania.

5. Kontrola serologiczna po leczeniu kiły opiera się na ocenie miana odczynu klasycznego - VDRL/ RPR (najlepiej wykonanego w tym samym laboratorium i za pomocą tych samych odczynników); wizyty kontrolne i badania po leczeniu kiły wczesnej należy wykonać co najmniej w 1., 3., 6. i 12. miesiącu po leczeniu. Potwierdzeniem wyleczenia kiły wczesnej jest obniżenie 4-krotne (o dwa rozcieńczenia) miana odczynu niekrętkowego w ciągu 6-12 miesięcy, a najlepiej jego negatywizacja po 1-2 latach. Odczyny krętkowe nie są przydatne w kontroli serologicznej po leczeniu kiły. Po terapii kiły późnej, jeśli odczyn klasyczny pozostaje w niskim mianie, dłuższa kontrola po leczeniu nie jest rekomendowana w zaleceniach europejskich. Wydaje się jednak, że przedłużenie kontroli klinicznej i serologicznej do 2 lat nie może mieć negatywnych konsekwencji dla pacjenta, a może wiarygodnie potwierdzić skuteczność leczenia.

6. W przypadku pacjentów z kiłą pierwszego okresu należy zbadać wszystkie kontakty z ostatnich 3 miesięcy, w przypadku pacjentów z kiłą drugiego okresu i utajoną wczesną - z ostatnich 2 lat, a pacjentów z kiłą późną (lub o nieznanym czasie trwania) - jeszcze wcześniejsze. Powinno się rozważyć leczenie epidemiologiczne kontaktów, gdy nie mogą się zgłosić do kontroli klinicznej i serologicznej (wskazane badanie w dniu pierwszej wizyty, po 6 tygodniach i 3 miesiącach). Jest to szczególnie ważne w przypadku kobiet w ciąży.

Przedstawione powyżej zalecenia stanowią najlepszą obecnie opcję diagnostyki i terapii kiły w Europie, opartą na dostępnych dowodach medycznych. 
Z tego względu Zarząd PTD oraz Sekcja Wenerologiczna PTD rekomendują adaptowane zalecenia do stosowania przez polskich dermatologów i wenerologów.

\section{Piśmiennictwo}

1. Janier M., Hegyi V., Dupin N., Unemo M., Tiplica G.S., Potocnik M. i inni: 2014 European guideline on the management of syphilis. JEADV 2014, 28, 1581-1593.
2. Instytut Wenerologii Akademii Medycznej w Warszawie: Zalecenia dotyczące leczenia i obserwacji po leczeniu kiły. Pismo z dnia 16 V 1974 (LWO/137-VIII/74).

3. French P., Gomberg M., Janier M., Schmidt B., van Voorst Vader P., Young H.: IUSTI: 2008 European guidelines on the management of syphilis. Int J STD AIDS 2009, 20, 300-309.

4. Kingston M., French P., Goh B., Goold P., Higgins S., Sukthankar A. $\mathrm{i}$ inni: UK national guidelines on the management of syphilis 2008. Int J STD AIDS 2008, 19, 729-740.

$\begin{array}{ll}\text { Otrzymano: } & 24 \text { VI } 2015 \mathrm{r} . \\ \text { Zaakceptowano: } & 4 \text { VIII } 2015 \mathrm{r} .\end{array}$ 